\section{References}

Alphin, R. S., Funderburk, W. H., and Ward, J. W. (1964). Toxicology and Applied Pharmacology, 6, 340 .

Anand, B. K. (1971). South African Medical fournal, 45, Suppl. No. 12.

Anand, B. K., and Blundell, J. E. (1971). South African Medical fournal, 45, Suppl. No. 53.

Bergmeyer, H. U., and Bernt, E. (1963). In Methods of Enzymatic Analysis, ed. H. U. Bergmeyer, p. 125. Weinheim, Verlag Chemic.

Besser, G. M., Butler, P. W., and Landon, J. (1969). British Medical fournal, 1,528 .

Blackard, W. G., and Heidingsfelder, S. A. (1968). fournal of Clinical Investigation, 47, 1407

Butterfield, W. J. H., and Whichelow, M. J. (1968). Lancet, 2, 109.

Costa, E., Groppetti, A., and Revuelta, A. (1971). British fournal of Pharmacology, 41, 57.

Cryer, P. E., and Daughaday, W. H. (1969). Fournal of Clinical Endocrinology, $29,386$.

Dannenburg, W. N., and Kardian, B. C. (1969). Archives Internationales de Pharmacodynamie, 196, 210.

Duncan, E. H., Regan, N. A., Hyde, C. A., and Sweetman, B. (1965). British fournal of Clinical Practice, 19, 451.

Eddy, R. L., Jones, A. L., Chakmakjian, Z. H., and Silverthorne, M. C. (1971). Fournal of Clinical Endocrinology, 33, 709.

Forhman, L. A. (1972). New England fournal of Medicine, 286, 1391.

Foxwell, M., Funderburk, W. H., and Ward, J. W. (1968). Fournal of Pharmacology, 165, 60 .

Fuxe, K., and Hökfelt, T. (1969). In Neuroendocrinology, ed. W. F. Ganong. and L. Martini, p. 47. London, Oxford University Press.

Hohorst, H., Kreutz, F. H., and Bücher, T. (1959). Biochemische Zeitschrift, 332, 18.
Hunter, W. M. (1969). Excerpta Medica International Congress Series, No 161, p. 5 and part 3, p. 551

Hunter, W. M., Fonseka, C. C., and Passmore, R. (1965). Biochemical fournal, 96,75p.

Hunter, W. M., and Ganguli, P. C. (1971). In Radio-Immuno Assay Methods, ed. K. E. Kirkham and W. M. Hunter, p. 243. Edinburgh, Churchill Livingstone.

Hunter, W. M., and Greenwood, F. C. (1964). British Medical fournal, 1, 804.

Itaya, K., and Ui, M. (1965). Fournal of Lipid Research, 6, 16.

Johnson, R. H., and Rennie, M. J. (1973). Clinical Science, 44, 63.

Kansal, P. C., Buse, J., Talbert, O. R., and Buse, M. G. (1972). Fournal of Clinical Endocrinology and Metabolism, 34, 99.

Lawrence, A. M., Goldfine, I. D., and Kirsteins, L. (1970). Fournal of Clinical Endocrinology and Metabolism, 31, 239.

Le Douarec, J. C., and Schmitt, H. (1964). Therapie, 19, 831.

McCann, S. M. (1970). In The Hypothalamus, ed. L. Martini, M. Molta, and F. Fraschini, p. 277. London, Academic Press.

Morgan, C. R., and Lazarow, A. (1968). Diabetes, 12, 115.

Munro, J. F., Seaton, D. A., and Duncan, L. J. P. (1966). British Medical Fournal, 2,624

Pawan, G. L. S. (1969). Lancet, 1, 498.

Traherne, J. B. (1965). Practitioner, 195, 677.

Williamson, D. H., Mellanby, J., and Krebs, H. A. (1962). Biochemical fournal, 82, 90 .

Wilson, J. P. D., and Galton, D. J. (1971). Hormone and Metabolic Research 3,262 .

Wurtman, R. J. (1970). In Hypophysiotropic Hormones of the Hypothalamus ed. J. Meites, p. 184. Baltimore, Williams and Wilkins.

Ziance, R. J., Sipes, I. G., Kinnard, W. J., and Buckley, J. P. (1972) fournal of Pharmacology, 180, 110.

\title{
Remission of Thyrotoxicosis during Treatment with Propranolol
}

\author{
D. G. MCLARTY, \\ B. E. W. BROWNLIE, \\ W. D. ALEXANDER, \\ P. D. PAPAPETROU, \\ P. HORTON
}

British Medical fournal, 1973, 2, 332-334

\section{Summary}

Twenty-eight thyrotoxic patients were treated with propranolol. In seven patients the drug had to be discontinued after one or two months, but in the remaining 21 clinical improvement was observed. Serial clinical studies and tests of thyroid function performed at monthly intervals showed that in four patients thyrotoxicosis remitted and all indices of thyroid function returned to normal. A fifth patient shows distinct evidence of remission with the 20minute ${ }^{132}$ I uptake falling to normal, although the freethyroxine index remains slightly raised. It is likely that these remissions reflect the natural tendency of the disease to remit since propranolol is not considered to have any direct in-vivo effect on thyroid function.

However, because of failure to gain adequate control of symptoms in all patients treated, and the fact that circulating thyroid hormone levels were often not restored to normal, propranolol is considered an unsatisfactory alternative to conventional antithyroid drugs for routine treatment.

\footnotetext{
University Department of Medicine, Gardiner Institute, Western Infirmary, Glasgow G11 6NT

D. G. McLARTY, M.B., M.R.C.P., Registrar, (Present appointment Lecturer, Department of Materia Medica, Stobhill Hospital Glasgow)

B. E. W. BROWNLIE, M.D., M.R.A.C.P., Research Fellow, (Present appointment: Physician in Charge, Radioisotope Department, Christchurch Hospital, Christchurch, New Zealand)

W. D. ALEXANDER, M.D., F.R.C.P., Reader

P. D. PAPAPETROU, M.D., Research Fellow, (Present appointment Instructor in Medicine, Department of Endocrinology, New England Instructor in Medicine, Department of Endocrinolo

P. HORTON, B.SC., PH.D., Principal Physicist (Present address: Department of Clinical Physics and Bioengineering, West Graham Street, Glasgow)
}

\section{Introduction}

If thyrotoxic patients are given a conventional course of treatment with antithyroid drugs, about $30-50 \%$ experience a prolonged remission and the remainder relapse (Hershman et al., 1966; Alexander et al., 1973). It has usually been thought that antithyroid drugs do not fundamentally affect the course of the disease, but merely inhibit thyroid hormone production until a natural remission occurs. If this is true it would be expected that the rate and frequency of remission of thyrotoxicosis would be independent of the drug used-whether, for example, a patient was treated with carbimazole or propranolol.

In this study remission occurred in several patients treated with propranolol alone in spite of the drug having no direct in-vivo effect on thyroid function (Hadden et al., 1969; Biran and Tal, 1972). Although it has been proposed that propranolol might be suitable as a definitive form of therapy for mild cases of thyrotoxicosis (Pimstone et al., 1969) our evidence suggests that this drug is not an acceptable alternative to conventional antithyroid drug therapy.

\section{Patients and Methods}

Twenty-eight patients were treated with propranolol. Thyrotoxicosis was confirmed by the presence of clinical features of the disease, a free thyroxine index (Clark and Horn, 1965) greater than 8, and in all patients the 20-minute ${ }^{132}$ I uptake (Alexander et al., 1969) was above $8 \%$.

Since effective treatment with standard antithyroid drugs is available we did not think that a strictly controlled clinical trial with random allocation of patients was ethically justifiable. Therefore, patients with severe clinical features 
were excluded from the study. Three of the patients had completed a previous course of antithyroid drugs two to 22 years previously, and two had had a thyroidectomy 10 and 17 years previously. Propranolol was given throughout the period of treatment in a dose of $40 \mathrm{mg}$ three times daily, except in four patients where the dose was increased to $40 \mathrm{mg}$ four times daily. The patients were reviewed monthly when a therapeutic index (Crooks et al., 1960) was completed and the patient was weighed. Serial measurements were made of the 20-minute thyroid ${ }^{132} \mathrm{I}$ uptake and pertechnetate ${ }^{99 m}$ Tc uptakes (Alexander et al., 1969), protein bound iodine, triiodothyronine ( $\mathrm{T}-3)$ resin uptake, and free thyroxine index (Clark and Horn 1965). If no improvement was observed in the patient's clinical state by one month, propranolol was discontinued and carbimazole substituted. If, however, there was an improvement the drug therapy was continued, usually for six months. If by six months there was a complete absence of clinical signs of thyrotoxicosis and thyroid function tests showed distinct evidence of improvement, propranolol was continued for a longer period.

The mean age of the patients was 44 years (range 21-58). Changes in the 20 -minute uptake of ${ }^{132} \mathrm{I}$ and ${ }^{99} \mathrm{mTc}$ over the six-month period were sought by comparing the uptakes at control and after six months using the $t$ test.

\section{Results}

\section{CLINICAL}

Propranolol was discontinued by the end of two months in seven of the 28 patients-in six because of inadequate control, and in one because of abdominal pain. Of the remaining 21 patients one completed four months' therapy with propranolol, one completed five months, and the remainder a minimum of six months' treatment. Nine patients were continued on propranolol for periods longer than six months.

Although symptomatic and objective improvement was observed in all patients treated for longer than one month, we found that by the end of the six-month period two patients continued to complain of occasional palpitations, four of continuing breathlessness on exertion, seven of tiredness, eight of sweating and heat intolerance, and four of continuing slight nervousness. The mean weight of the patients before propranolol was started was 55.2 \pm S.D. $10.5 \mathrm{~kg}$, at three months $55.1 \pm 10.4 \mathrm{~kg}$, and at six months $57.4 \pm 11.4 \mathrm{~kg}$. The mean pulse rate before propranolol was started was $111 \pm 14$ beats $/ \mathrm{min}$, at three months 78 \pm 10 beats $/ \mathrm{min}$, and at six months $78 \pm 9$ beats $/ \mathrm{min}$.

The protein bound iodine, T-3 resin uptake, and free thyroxine index showed no significant change over the sixmonth period (see table). The mean ${ }^{132}$ I uptake was initially

Values obtained at Control, Three Months, and Six Months in 21 Thyrotoxic Patients Treated with Propranolol (Mean \pm S.D.)

\begin{tabular}{|c|c|c|c|c|}
\hline & Control & $\begin{array}{l}\text { Three } \\
\text { Months }\end{array}$ & $\underset{\text { Months }}{\text { Six }}$ & $\begin{array}{l}\text { Signifi- } \\
\text { cance }\end{array}$ \\
\hline $\begin{array}{l}20-\text { min }{ }^{132} \text { I uptake }(\%) \\
20-\text { min } 99 \text { Tc uptake }(\%) \\
\text { Protein bound iodine }(\mu \mathrm{g})\end{array}$ & $\begin{array}{l}38 \cdot 3 \pm 19 \cdot 2 \\
20 \cdot 7 \pm 12 \cdot 8\end{array}$ & $\begin{array}{l}32 \cdot 2 \pm 16 \cdot 8 \\
18 \cdot 9 \pm 10 \cdot 0\end{array}$ & $\begin{array}{l}30.2 \pm 19.5 \\
15.8 \pm 11.3\end{array}$ & $\begin{array}{l}\text { N.S. } \\
\text { N.S. }\end{array}$ \\
\hline $\begin{array}{l}100 \mathrm{ml}) \\
\mathrm{T}-3 \text { resin uptake }(\%) \\
\text { Free thyroxine index }\end{array}$ & $\begin{array}{l}13 \cdot 2+2 \cdot 6 \\
43 \cdot 5 \pm 6 \cdot 1 \\
17.9 \pm 5 \cdot 1\end{array}$ & $\begin{array}{l}14.0 \pm 3.1 \\
41.7 \pm 6.5 \\
18.8 \pm 5.9\end{array}$ & $\begin{array}{l}12.3 \pm 3.9 \\
40.0 \pm 7.1 \\
15.8 \pm 6.8\end{array}$ & $\begin{array}{l}\text { N.S. } \\
\text { N.S. } \\
\text { N.S. }\end{array}$ \\
\hline
\end{tabular}

N.S. = Not significant.

$38.3 \%$ and was $30.2 \%$ after six months' treatment. These values were not significantly different $(P>0.10)$. The mean

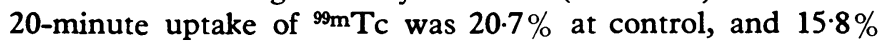
after six months' treatment. Again these values were not significantly different $(P>0.20)$.
INCIDENCE OF REMISSION

All indices of thyroid function were seen to return to normal in four of the 21 patients who continued on propranolol for a period longer than two months. The mean period of treatment in these 21 patients was eight months. Remission occurred in two patients within six months (cases 1 and 2, figs. 1 and 2). The third patient went into remission by the eighth month of treatment, and the fourth by the 16th month.

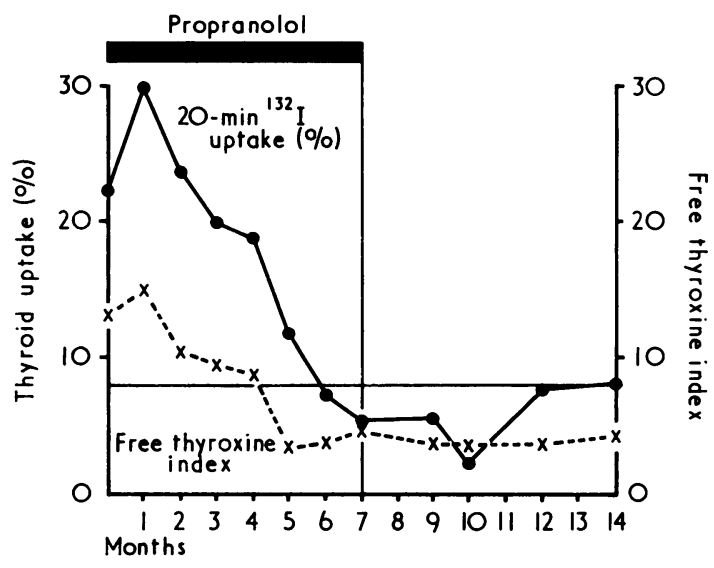

FIG. 1-Case 1. Thyroid uptake and free thyroxine index during treatment.

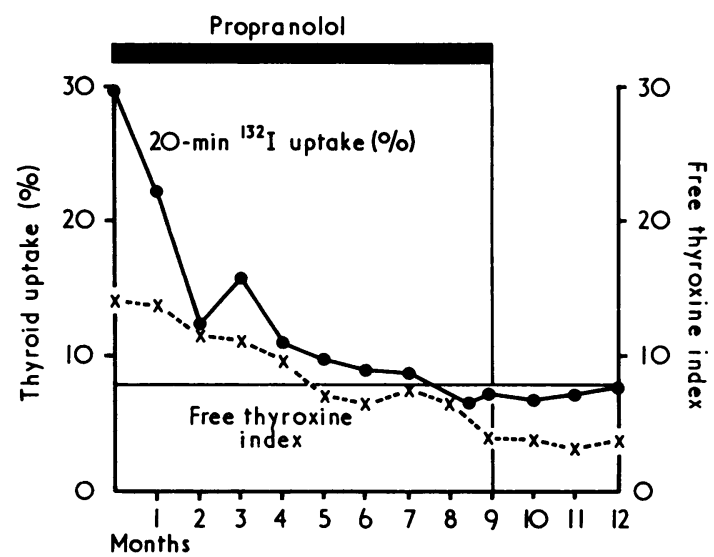

FIG. 2-Case 2. Thyroid uptake and free thyroxine index during treatment.

Case 1.-Woman aged 37. Seven-month history of heat intolerance, excessive sweating, and periorbital puffiness. Clinically thyrotoxic. Goitre $40 \mathrm{~g}$, diffuse. Pretreatment 20-minute ${ }^{132} \mathrm{I}$ uptake $22.3 \%$ (upper limit of normal 8\%). Free thyroxine index 13.5 (upper limit of normal 8). By the sixth month of treatment all parameters of thyroid function had returned to normal. Since stopping propranolol she remained well and clinically euthyroid (fig. 1).

Case 2.-Woman aged 49. Tiredness, breathlessness, nervousness, and weight loss for six months. Clinically thyrotoxic. Goitre $75 \mathrm{~g}$, diffuse. Pretreatment 20 -minute ${ }^{132}$ I uptake $29.6 \%$, free thyroxine index 14.3. By the fifth month of treatment the free thyroxine index was 6.9. She remained symptom-free and clinically euthyroid, although she still had a large goitre (fig. 2).

Case 3.-Woman aged 47. Three-month history of prominence of left eye and weight loss of $1 \mathrm{st}(6 \cdot 4 \mathrm{~kg})$. Clinically thyrotoxic. Small $30-40-\mathrm{g}$ goitre. Pretreatment 20 -minute ${ }^{132} \mathrm{I}$ uptake $8.7 \%$ and free 
thyroxine index $8 \cdot 4$. By the eighth month of treatment all parameters of thyroid function had returned to normal, and she remained clinically euthyroid.

Case 4.-Woman aged 57. History of prominence of right eye and gradual weight loss for six months. No other symptoms. Clinically mildly thyrotoxic. Goitre $30 \mathrm{~g}$. Pretreatment 20 -minute ${ }^{132}$ I uptake $12.9 \%$, free thyroxine index $20 \cdot 5$. Remained clinically euthyroid when propranolol stopped after 12 months. Pulse $80 / \mathrm{min}$, regular. Free thyroxine index returned to normal at the 16 th month. She remained well and symptom-free.

A similar pattern was observed in a fifth patient in whom the 20 -minute ${ }^{132}$ I uptake fell below 8 by the ninth month of treatment, but the free thyroxine index remained just above the upper limit of normal. The patient was symptomfree and clinically euthyroid, and his weight increased from 64 to $71 \mathrm{~kg}$.

\section{Discussion}

While no significant change in the ${ }^{132} \mathrm{I}$ uptake and ${ }^{66 \mathrm{~m}} \mathrm{Tc}$ uptake after six months of propranolol therapy had occurred in the group of 21 patients receiving long-term treatment, a definite fall in uptake was observed in individual patients. By six months the disease had remitted in two patients, and at later times all indices of thyroid function had returned to normal in a further two patients. A fifth patient showed evidence of remission with the 20-minute ${ }^{132}$ I uptake within normal limits, although the free thyroxine index remained slightly raised. It is probable that the decline in thyroid uptake and level of circulating hormone in these patients reflects the natural tendency of the disease to remit, since propranolol is thought not to have any in-vivo effect on thyroid hyperactivity or on the rate of thyroid hormone secretion. There is, therefore, no doubt that prolonged remission may occur during treatment with propranolol. However, since treatment had to be withdrawn in seven patients after one or two months, and since circulating levels of thyroid hormone did not consistently return to normal in the remainder who received the long-term therapy, propranolol cannot be recommended as a definitive form of therapy for the treatment of thyrotoxicosis.

Furthermore, the metabolic consequences of long-term adrenergic blockade in thyrotoxicosis have not been fully elucidated-for example, the possibility of progressive osteoporosis in some patients exists. Nevertheless it is clear that propranolol has a place in the treatment of thyrotoxicosis in special circumstances (Vinik et al., 1968; Das and Krieger, 1969; Becker and Schwartz, 1972). In this series no significant adverse effects were noted and serum transaminases remained within normal limits. It may be asked if an increase in the dose of propranolol administered might have resulted in a more complete control of symptoms, but the dose administered, $40 \mathrm{mg}$ three times daily, was adequate to consistently restore the pulse rate to normal.

It is not possible from the present study to compare remission rate during treatment with propranolol with that following conventional antithyroid drug therapy, since most workers have given antithyroid drugs for longer periods. It must also be remembered that seven patients had to be excluded from the analysis shown in the table, and patients with severe symptoms were in any case not included in the series. Pimstone et al. (1969) observed that in $22 \%$ of 27 thyrotoxic patients treated with propranolol alone for a mean period of five months the radioactive uptakes fell to normal, but no estimate of the level of circulating thyroid hormone was reported. We have observed that the radioiodine uptake may return to normal before circulating hormone levels. Our evidence does not support the suggestion that propranolol may be a suitable alternative to treatment with conventional antithyroid drugs in milder cases of thyrotoxicosis.

We thank the Medical Research Council for financial support.

\section{References}

Alexander, W. D., Harden, R. McG., and Shimmins, J. (1969). Recent Progress in Hormone Research, 25, 423.

Alexander, W. D., McLarty, D. G., Horton, P., and Pharmakiotis, A. D. (1973). Clinical Endocrinology, 2, 43.

Becker, F. O., and Schwartz, T. B. (1972). Archives of Internal Medicine, 129, 967 .

Biran, S., and Tal, E. (1972). Fournal of Clinical Pharmacology, 12, 105. Clark, F., and Horn, D. B. (1965). Fournal of Clinical Endocrinology and Metabolism, 25, 39

Crooks, J., Wayne, E. J., and Robb, R. A. (1960). Lancet, 1, 397.

Das, G., and Krieger, M. (1969). Annals of Internal Medicine, 70, 985.

Hadden, D. R., et al. (1969). Acta Endocrinologica, (Kobenhavn), 61, 393.

Hershman, J. M., Givens, J. R., Cassidy, C. E., and Astwood, E. B. (1966) fournal of Clinical Endocrinology and Metabolism, 26, 803.

Fournal of Clinical Endocrinology and Metabolism, 26, 803 .
Pimstone, B., Joffe, B., Pimstone, N., Bonnici, F., and Jackson, W. P. U. (1969). South African Medical fournal, 43, 1203.

Vinik, A. I., Pimstone, B. L., and Hoffenberg, R. (1968). Fournal of Clinical Endocrinology, and Metabolism 28, 725.

\title{
Hepatitis B Antigen Inhibitor in Human Faeces and Intestinal Mucosa
}

\author{
M. PIAZZA, \\ G. Di STASIO, \\ G. MAIO, \\ L. A. MARZANO
}

British Medical fournal, 1973, 2, 334- 337

\section{Summary}

Hepatitis B antigen (HB Ag) positive sera became negative after in-vitro incubation with homogenates of human faeces or intestinal mucosa. This was found to occur in all sera

\footnotetext{
Department of Infectious Diseases, University of Naples, Nuovo Policlinico, Cappella dei Cangiani, Naples, Italy

M. PIAZZA, M.D., Professor and Director

G. DI STASIO, M.D., Libero Docente of Infectious Diseases

G. DI STASIO, M.D., Liberc

L. A. MARZANO, M.D., Assistant
}

tested by various methods. These findings suggest the existence in the human intestine of a substance able to inactivate the $\mathrm{HB} \mathrm{Ag}$ and that it is not an antibody or of the nature of interferon. The presence of an inhibitor could explain why B-type hepatitis is seldom if ever faecally transmitted and also the low oral infectiousness of the $B$ virus.

\section{Introduction}

B-type serum hepatitis, despite a presumably high concentration of virus in the liver and bile, seems seldom to be faecally transmitted (Krugman et al., 1967; Krugman and 